Journal of Animal and Veterinary Advances 10 (19): 2523-2527, 2011

ISSN: $1680-5593$

(C) Medwell Journals, 2011

\title{
Methane Production and Methanogen Population in Rumen \\ Liquor of Swamp Buffalo as Influenced by Coconut Oil and Mangosteen Peel Powder Supplementation
}

\author{
Ruangyote Pilajun and Metha Wanapat \\ Tropical Feed Resources Research and Development Center (TROFREC), \\ Department of Animal Science, Faculty of Agriculture, \\ Khon Kaen University, 40002 Khon Kaen, Thailand
}

\begin{abstract}
An in vitro study was conducted to evaluate effect of coconut oil and Mangosteen Peel Powder (MPP) supplementation on methane production and methanogen population in rumen liquor of swamp buffalo. Completely randomized design was used with nine treatments including control and supplementation with coconut oil ( $3,6 \% \mathrm{DM})$ and/or MPP $(2,4 \% \mathrm{DM})$. Supplementation of coconut oil and MPP significantly reduced methane production when compared with control group $(\mathrm{p}<0.05)$ however, increasing coconut oil and MPP levels decreased proportion of methane reduction. Population of methanogen was unchanged by supplementations $(p>0.05)$ in contrast, the methanogen diversity slightly differed among treatments, especially when combinations with coconut oil and MPP used. The UPGMA dendrogram showed supplementation of coconut oil and MPP combination had pronounced effect on gel profile than that of single supplementation, especially combination of $6 \%$ of coconut oil with $2 \%$ of MPP which resulted in lowest band numbers. In addition, supplementation by high level of coconut oil or MPP did not show positive effects. Therefore, suitable level should not exceed than $6 \%$ for coconut oil and 4\% DM for MPP supplementations, respectively.
\end{abstract}

Key words: Coconut oil, mangosteen peel powder, methane, methanogen, swamp buffalo, rumen liquor

\section{INTRODUCTION}

Ruminant animals are one of the largest sources of methane emission with 81-92 million tons produced per year globally which is equivalent to $23-27 \%$ of total anthropogenic methane (IPCC, 2007). Methane produced during ruminal fermentation represents a loss of $2-15 \%$ of gross energy intake and thus decreases the potential conversion of digesta to metabolisable energy (Giger-Reverdin and Sauvant, 2000).

Fat inclusion in the diet causes a marked decrease in methane production by rumen fluid with the effect being at least partly governed by the fat source used (Soliva et al., 2003; Machmuller, 2006). Most recently, Kongmun et al. (2010) reported that supplementation of coconut with garlic powder could improve in vitro ruminal fluid fermentation in terms of volatile fatty acid profile, reduced methane losses and reduced protozoal population. Moreover, there have been reports of decreased methane emission by ruminants consuming plant secondary compounds (Carulla et al., 2005; Puchala et al., 2005). Supplementation of pellets containing condensed tannins and saponins (MP and soapberry fruit) influenced rumen ecology by significantly lowering methane concentration in rumen atmosphere and reduced methanogen population (Poungchompu et al., 2009). Thus, the objective of the present study was to investigate effect of coconut oil and MPP supplementation on methane production and methanogens population in in vitro by used rumen fluid of swamp buffalo.

\section{MATERIALS AND METHODS}

Experimental design and gas production technique: An in vitro study was conducted to evaluate effect of coconut oil and MPP supplementation on methane production and methanogens population. Completely randomized design was used with nine treatments including control and supplementation with coconut oil $(3,6 \% \mathrm{DM})$ and/or MPP $(2,4 \% \mathrm{DM})$. The method used for in vitro fermentation based on the technique described by Menke et al. (1979).

Sample collection and analysis: The gas samples were collected at $6,12,24,48$ and $72 \mathrm{~h}$ of incubation and stored for methane concentration analyzed by using Gas Chromatography with a Flame Ionization Detector

Corresponding Author: Metha Wanapat, Tropical Feed Resources Research and Development Center (TROFREC), Department of Animal Science, Faculty of Agriculture, Khon KaenUniversity, 40002 Khon Kaen, Thailand 
(GC/FD). The fermented content were sampled at $12 \mathrm{~h}$ of fermenting and was fixed in $1 \%$ formalin for microbial population analyzed using molecular techniques.

Community Deoxyribonucleic Acids (DNA) extraction: Community DNA was extracted from $2 \mathrm{~mL}$ of rumen fluid by the $\mathrm{RBB}+\mathrm{C}$ method described by $\mathrm{Yu}$ and Morrison (2004). In brief, the cell lysis is achieved by bead-beating in the presence of $4 \%(\mathrm{w} / \mathrm{v})$ Sodium Dodecylsulfate (SDS), $500 \mathrm{mM} \mathrm{NaCl}$ and $50 \mathrm{mM}$ EDTA.

After bead-beating, most of the impurities and the SDS are removed by precipitation with ammonium acetate and then the nucleic acids are removed by precipitation with isopropanol. Genomic DNA can then purified via sequential digestion with RNase $\mathrm{A}$ and proteinase $\mathrm{K}$ and the DNA are purified using columns from QIAgen DNA Mini Stool Kit (QIAGEN, Valencia, CA).

Quantitative analysis of methanogen populations: Real-time PCR amplification and detection was performed using a Choromo4 detection system (Bio-Rad, Hercules, $\mathrm{CA}$ ). The reaction was conducted in a final volume of $10 \mu \mathrm{L}$ containing the following: $5.1 \mu \mathrm{L}$ Quatimix EASY SYG Kit (BIOTOOLS B and M Labs, S.A.), $0.408 \mu \mathrm{L}$ as a forward primer, $0.408 \mu \mathrm{L}$ as a reverse primer, $2.244 \mu \mathrm{L}$ distilled water and $2.0 \mu \mathrm{L}$ of DNA solution of unknown concentration. PCR primers used for methanogen are $\mathrm{F}$ 5'-TTCGGTGGATCDCARAGRGC-3' and R 5'-GBARG TCGWAWCCGTAGAATC C-3' (Denman et al., 2007). Regular PCR conditions for were as follows: $30 \mathrm{sec}$ at $94^{\circ} \mathrm{C}$ for denaturing, $30 \mathrm{sec}$ at $60^{\circ} \mathrm{C}$ for annealing and $30 \mathrm{sec}$ at $72^{\circ} \mathrm{C}$ for extension (48 cycles), except for $9 \mathrm{~min}$ denaturation in the first cycle and 10 min extension in the last cycle.

Denaturing Gradient Gel Electrophoresis (DGGE)analyses: The PCR amplification for methanogen was conducted in a total volume of $50 \mu \mathrm{L}$ containing $0.5 \mu \mathrm{M}$ of primers (F 5'-GC-clamp-ACGGGGYGCA GCAGGCGCGA-3' and R 5'-GWATTAC CGCGGCKGCTG-3'; Bano et al., 2004), $80 \mu \mathrm{M}$ of dNTP mixed, $1.75 \mathrm{mM}$ of $\mathrm{MgCl}_{2}, 1 \times \mathrm{PCR}$ buffer $1 \times \mathrm{GC}$ buffer and $1.25 \mathrm{U}$ of platinum taq $\mathrm{DNA}$ polymerase.

The DNA templates were first subjected to an initial denaturation at $95^{\circ} \mathrm{C}$ for $5 \mathrm{~min}, 30 \mathrm{sec}$ at $95^{\circ} \mathrm{C}$ for denaturing, $30 \mathrm{sec}$ at $61^{\circ} \mathrm{C}$ and decrease $0.5^{\circ} \mathrm{C} \mathrm{cycle}^{-1}$, $1 \mathrm{~min}$ at $72^{\circ} \mathrm{C}(10$ cycles $), 30 \mathrm{sec}$ at $95^{\circ} \mathrm{C}$ for denaturing, $30 \mathrm{sec}$ at $56^{\circ} \mathrm{C}$ for annealing, $1 \mathrm{~min}$ at $72^{\circ} \mathrm{C}$ for extension ( 25 cycles) and $72^{\circ} \mathrm{C}$ for $30 \mathrm{~min}$. The products were resolved on $80 \mathrm{~g} \mathrm{~L}^{-1}$ polyacrylanide gel (37.5:1) with a $300-600 \mathrm{~g} \mathrm{~L}^{-1}$ denaturing gradient for $5 \mathrm{~min}$ at 200 voltage and then for $16 \mathrm{~h}$ at 85 voltage. After the run, gels were stained for $30 \mathrm{~min}$ in $0.5 \times$ Tris-borate-EDTA buffer containing SYBR Gold nucleic acid stain (Molecular Probes, Eugene, OR) and gel images were captured using Photo documentation (Vilber Lourmat, France). The gel images were analyses by using the Phoretix 1D advanced analysis package.

Profiles were compared by hierarchical clustering to join similar patterns into groups (Fromin et al., 2002). To this end all the images of DGGE gels were matched using the internal control sample and the bands were quantified after local background subtraction. The similarity among profiles was calculated with the Pearson product-moment correlation coefficient and the clustering was done with the Unweighted Pair-Group method using Arithmetic averages (UPGMA; Mehmood et al., 2009). A significance test based on pairwise similarity measures was used to compare the community profiles of different groups of samples (Kropf et al., 2004).

Statistical analysis: Methane production and methanogen numbers were analyzed by using the General Linear Models (GLM) procedure (SAS Institute, 1996). Data were analyzed using the model:

Where:

$$
\mathrm{Y}_{\mathrm{ij}}=\mu+\mathrm{T}_{\mathrm{i}}+\varepsilon_{\mathrm{ij}}
$$

$\mathrm{Y}_{\mathrm{ij}}=$ Observation from treatment $\mathrm{i}, \mathrm{j}$, the replication

$\mu=$ Overall mean

$\mathrm{T}_{\mathrm{i}}=$ Mean of treatment

$\varepsilon_{\mathrm{ij}}=$ Residual effect

Mean separations with a significant $F(p<0.05)$ for treatment will be statistically compared using the orthogonal contrast.

\section{RESULTS AND DISCUSSION}

Methane production: Methane production has been shown to be affected by feed supplementation $(\mathrm{p}<0.05$; Table 1). Supplementation of coconut oil and MPP reduced methane production in various time, especially at 48th $h$ after fermentation which was significantly different when compared with control group ( $\mathrm{p}<0.01$ ). Combination of coconut oil with MPP decreased methane production in all sampling times $(\mathrm{p}<0.05)$ however, increasing both coconut oil and MPP levels decreased proportion of methane reduction $(\mathrm{p}<0.05)$. These results agreed with previous study in in vitro (Kongmun et al., 2010) and in vivo (Machmuller and Kreuzer, 1999). Moreover, other studies have shown that dietary supplementation with medium chain fatty acid, rich in coconut oil, depressed methane production (Yabuuchi et al., 2006; Odongo et al., 
Table 1: Effect of feed supplementation on methane production and Log quantity of methanogen population determined by real-time PCR

\begin{tabular}{|c|c|c|c|c|c|c|}
\hline \multirow[b]{2}{*}{ Treatments } & \multicolumn{4}{|c|}{ Methane production $(\mathrm{mL})$} & \multicolumn{2}{|c|}{ Methanogen no. } \\
\hline & $6 \mathrm{~h}$ & $12 \mathrm{~h}$ & $24 \mathrm{~h}$ & $48 \mathrm{~h}$ & $72 \mathrm{~h}$ & $12 \mathrm{~h}$ \\
\hline Control & 8.60 & 16.30 & 21.1 & 22.1 & 23.3 & 4.94 \\
\hline $\mathrm{CO}(3 \%)$ & 7.10 & 15.4 & 20.4 & 15.8 & 22.6 & 5.04 \\
\hline $\mathrm{CO}(6 \%)$ & 7.50 & 13.3 & 18.2 & 12.1 & 15.0 & 5.00 \\
\hline CT $(2 \%)$ & 6.50 & 9.70 & 17.0 & 22.6 & 22.4 & 5.16 \\
\hline CT $(4 \%)$ & 7.50 & 7.70 & 20.4 & 21.8 & 21.6 & 4.94 \\
\hline $\mathrm{CO}(3 \%) \mathrm{MP}(2 \%)$ & 8.00 & 15.5 & 18.5 & 21.3 & 22.4 & 5.19 \\
\hline $\mathrm{CO}(3 \%) \mathrm{MP}(4 \%)$ & 7.30 & 8.80 & 16.1 & 20.4 & 20.4 & 5.03 \\
\hline $\mathrm{CO}(6 \%) \mathrm{MP}(2 \%)$ & 7.50 & 13.6 & 18.1 & 20.6 & 21.6 & 4.96 \\
\hline $\mathrm{CO}(6 \%) \mathrm{MP}(4 \%)$ & 7.80 & 13.9 & 17.6 & 14.9 & 20.6 & 4.73 \\
\hline SEM & 0.24 & 0.64 & 1.18 & 1.29 & 1.39 & 0.11 \\
\hline \multicolumn{7}{|l|}{ Contrast } \\
\hline Control vs. supp & $* * *$ & $* *$ & $* *$ & $* *$ & $* *$ & NS \\
\hline Control vs. CO & $*$ & $* *$ & $* *$ & $* *$ & NS & NS \\
\hline Control vs. MP & NS & NS & *** & $* *$ & $* *$ & NS \\
\hline Control vs. COMP & *** & *** & $* *$ & $* *$ & $*$ & NS \\
\hline CO vs. MP & NS & $* *$ & NS & $* *$ & $* *$ & NS \\
\hline $\begin{array}{l}\mathrm{CO}(3 \%) \mathrm{vs} \\
\mathrm{CO}(6 \%)\end{array}$ & NS & $* * *$ & NS & $* * *$ & $* * *$ & NS \\
\hline $\begin{array}{l}\text { MP (2\%) vs. MP4 } \\
(\%)\end{array}$ & NS & $* *$ & NS & $* *$ & NS & $*$ \\
\hline \multicolumn{7}{|c|}{$\begin{array}{l}\text { CO }(3 \%)=\text { Supplemented with } 3 \% \text { DM of coconut oil, CO }(6 \%)= \\
\text { Supplemented with } 6 \% \text { DM of coconut oil, MP }(2 \%)=\text { Supplemented with } \\
2 \% \text { DM of mangosteen peel powder, MP }(4 \%)=\text { Supplemented with } 4 \% \\
\text { DM of mangosteen peel powder; }{ }^{* p}<0.05,{ }^{* *} p<0.01, \mathrm{NS}=\text { Non Significant } \\
\text { SEM = Standard Error of the Mean }\end{array}$} \\
\hline
\end{tabular}

2007). Machmuller (2006) stated that the methane suppressing effect of coconut oil is directly inhibit rumen methanogenic archaea and may change their metabolic activity. Methane production was also decreased with MPP supplementation and agreed with Poungchompu et al. (2009) who found that methane emission was depressed by inclusion of MPP and soapberry fruit pellet in dairy heifer diet. In this study, there was no MPP effect on dry matter or organic matter disappearance thus, the methane suppressing-effects of saponins were presumably a direct action against rumen microbes involved in methane formation including methanogens and protozoa (Sliwinski et al., 2002). Tavendale et al. (2005) proposed two mechanisms whereby condensed tannins reduced methane emissions from ruminants: indirectly through a reduction in fiber digestion which decreases $\mathrm{H}_{2}$ production and directly through an inhibition of the growth of methanogens. Moreover, Guo et al. (2008) concluded saponin appeared to reduce methane production by inhibiting protozoa and presumably lowering methanogenic activity of protozoal associated methanogens. In contrast, Beauchemin et al. (2007) failed to reduce enteric methane emissions from growing cattle by feeding the dietary DM as quebracho tannin extract. Reduction of methane production by tannin or saponins containing plant could be due to both kind of plant and proportion that animal received.

Methanogen population: Methanogen population was not impacted by feed supplementation ( $>>0.05$; Table 1) while methane production was decreased $(\mathrm{p}<0.05)$. However,

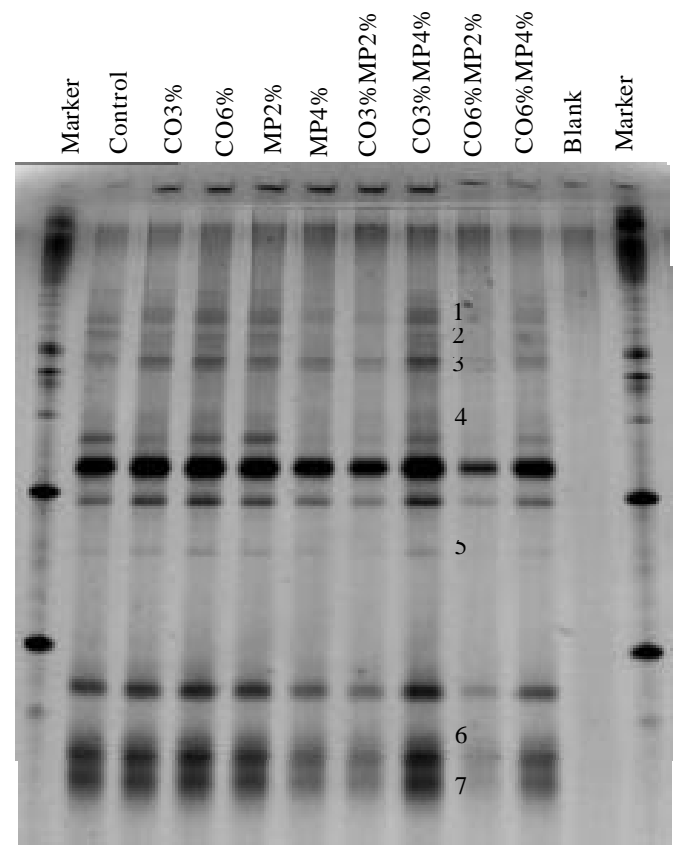

Fig. 1: Photographed gel after DGGE electrophoresis of methanogen $16 \mathrm{~s}$ rDNA fragments from 9 treatments of rumen fluid. $\mathrm{CO} 3 \%=$ supplementation of coconut oil at 3\%, CO6\% $=$ supplementation of coconut oil at $6 \%, \mathrm{MP} 2 \%=$ supplementation of mangosteen peel powder at $2 \%, \mathrm{MP} 4 \%=$ supplementation of mangosteen peel powder at $2 \%$

Soliva et al. (2003) reported that methane production and declined with an increasing proportion of luaric acid and confirmed the presumptions Dohme et al. (1999) who revealed that the methane suppressing effect of coconut oil was the results of a direct inhibition of ruminal methanogens. It indicated that feed supplementation likely effect on $\mathrm{CO}_{2}$ or $\mathrm{H}_{2}$, the precursor of methane synthesis or methanogenesis process greater than direct effect on methanogen population. The result analyzed by PCR-DGGE technique showed that the methanogen diversity appeared slightly differed among treatments especially when combinations of coconut oil and MPP were used (Fig. 1). There were seven difference bands separate from DGGE image was number of band was higher in supplementation of coconut oil than those in MPP groups. However, the UPGMA dendrogram show supplementation of coconut oil and MPP combination had more effect on gel profile than that single supplementation, especially combination of $6 \%$ of coconut oil with $2 \%$ of MPP which appeared lowest bane numbers (Fig. 2). However, coconut oil did not affect on DGGE band patterns information by Kongmun et al. (2011) and Hristov et al. (2009). This research found fifteen bands from DGGE gel image which were quite 


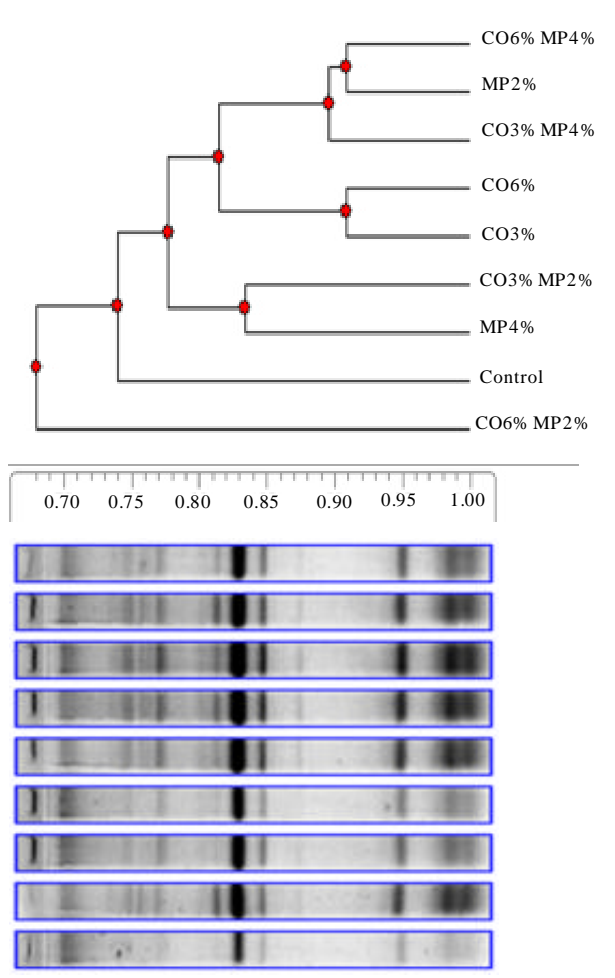

Fig. 2: The UPGMA dendrogram of methanogen $16 \mathrm{sDNA}$ fragments from 9 treatments of rumen fluid. $\mathrm{CO} 3 \%=$ supplementation of coconut oil at $3 \%$, CO6\% $=$ supplementation of coconut oil at $6 \%$, MP2\% = supplementation of mangosteen peel powder at $2 \%, M P 4 \%=$ supplementation of mangosteen peel powder at $2 \%$

similar with the research of Kongmun et al. (2011) who found almost thirteen separated bands from DGGE gel of rumen fluid from swamp buffaloes. However, earlier research of the team (Wanapat et al., 2011) found only seven separated bands in the rumen of the same animal species (Bubalus bubalis). On the other hand, it was found 9-10 bands in lactating cow (Hristov et al., 2009), 14 bands (4-9 bands per animal) in sheep (Wright et al., 2007) and 12-23 bands in feedlot cattle (Wright et al., 2008). However, increasing of MPP level (4\% DM) resulted in inverse effect which presented more ban in the DGGE gels. This may cause by other composition in the MPP such as crude protein and fiber, nitrogen and carbon sources for microbe (Hungate, 1966). In addition, identification of methanogen species by gene sequencing technique could provide more useful information concerning the bacterial diversity in the rumen.

\section{CONCLUSION}

Coconut oil and mangosteen peel powder supplementation decreased methane production by changing methanogen population. Although, methanogen population was not changed, methanogen diversity was relatively changed by dietary supplementation. Combination of coconut oil and mangosteen peel powder had pronounced effect than those of single supplementation. Supplementation by high level of coconut oil or mangosteen peel powder did not show positive effects. Thus, appropriate level should not exceed 6\% DM for coconut oil and 4\% DM for mangosteen peel powder supplementations.

\section{ACKNOWLEDGEMENTS}

The researchers wish to express sincere thanks to the Thailand Research Fund (TRF) through the Royal Golden Jubilee Ph.D. Program and to the Tropical Feed Resources Research and Development Center (TROFREC), Khon Kaen University, Thailand for providing financial support of research and research facilities and experimental animals. Laboratory equipment provided by the Agricultural Biotechnology Research Center, Khon Kaen University, Thailand was greatly appreciated.

\section{REFERENCES}

Bano, N., S. Ruffin, B. Ransom and J.T. Hollibaugh, 2004. Phylogenetic composition of arctic ocean archaeal assemblages and comparison with Antarctic assemblages. Applied Environ. Microbiol., 70: $781-789$.

Beauchemin, K.A., S.M. McGinn, T.F. Martinez and T.A. McAllister, 2007. Use of condensed tannin extract from quebracho trees to reduce methane emissions from cattle. J. Anim. Sci., 85: 1990-1996.

Carulla, J.E., M. Kreuzer, A. Machmller and H.D. Hess, 2005. Supplementation of Acacia mearnsii tannins decreases methanogenesis and urinary nitrogen in forage-fed sheep. Aust. J. Agric. Res., 56: 961-970.

Denman, S.E., N.W. Tomkins and C.S. McSweeney, 2007. Quantitation and diversity analysis of ruminal methanogenic populations in response to the antimethanogenic compound bromochloromethane. FEMS Microbiol. Ecol., 62: 313-322.

Dohme, F., A. Machmuller, A. Wasserfallen and M. Kreuzer, 1999. The role of the rumen ciliate protozoa for methane suppression caused by coconut oil. Lett. Applied Microbiol., 29: 187-192.

Fromin, N., J. Hamelin, S. Tarnawski, D. Roesti and K. Jourdain-Miserez et al., 2002. Statistical analysis of denaturing gel electrophoresis (DGE) fingerprinting patterns. Environ. Microbiol., 4: 634-643. 
Giger-Reverdin, S. and D. Sauvant, 2000. Methane production in sheep in relation to concentrate feed composition from bibliographic data. Proccedings of the 8th Seminar of the Sub-Network on Nutrition of the FAO-CIHEAM Inter-Regional Cooperative Research and Development Network on Sheep and Goats, INRA. Oct. 26-28, Cahiers-OptionsMediterraneennes, Grignon, France, pp: 43-46.

Guo, Y.Q., J.X. Liu, Y. Lu, W.Y. Zhu, S.E. Denman and C.S. McSweeney, 2008. Effect of tea saponin on methanogenesis, microbial community structure and expression of mcrA gene, in cultures of rumen microorganisms. Lett. Applied Microbiol., 47: 421-426.

Hristov, A.N., M. Vander Pol, M. Agle, S. Zaman and C. Schneider et al., 2009. Effect of lauric acid and coconut oil on ruminal fermentation, digestion, ammonia losses from manure, and milk fatty acid composition in lactating cows. J. Dairy Sci., 92: 5561-5582.

Hungate, R.E., 1966. The Rumen and its Microbes. 1st Edn., Academic Press, New York, USA., pp: 553.

IPCC, 2007. Climate Change 2007: Mitigation. Contribution of Working Group III to the Fourth Assessment Report of the Intergovernmental Panel on Climate Change. Cambridge University Press, Cambridge, UK and New York.

Kongmun, P., M. Wanapat, P. Pakdee and C. Navanukraw, 2010. Effect of coconut oil and garlic powder on in vitro fermentation using gas production technique. Livest. Sci., 127: 38-44.

Kongmun, P., M. Wanapat, P. Pakdee, C. Navanukraw and Z. Yu, 2011. Manipulation of rumen fermentation and ecology of swamp buffalo by coconut oil and garlic powder supplementation. Livest. Sci., 135: 84-92.

Kropf, S., H. Heuer, M. Gruning and K. Smalla, 2004. Significance test for comparing complex microbial community fingerprints using pairwise similarity measures. J. Microbiol. Methods, 57: 187-195.

Machmuller, A. and M. Kreuzer, 1999. Methane suppression by coconut oil and associated effects on nutrient and energy balance in sheep. Can. J. Anim. Sci., 79: 65-72.

Machmuller, A., 2006. Medium-chain fatty acids and their potential to reduce methanogenesis in domestic ruminants. Agric. Ecosyat. Environ., 112: 107-114.

Mehmood, M.K., E. Adetutu, D.B. Nedwell and A.S. Ball, 2009. In situ microbial treatment of landfill leachate using aerated lagoons. Bioresour. Technol., 100: 2741-2744.

Menke, K.H., L. Raab, A. Salewski, H. Steingass, D. Fritz and W. Schneider, 1979. The estimation of digestibility and metabolizable energy content of ruminant feedstuffs from the gas production when they incubated with rumen liquor in vitro. J. Agric. Sci. Camb., 92: 217-222.
Odongo, N.E., M.M. Or-Rashid, E. Kebreab, J. France and B.W. McBride, 2007. Effect of supplementing myristic acid in dairy cow rations on ruminal methanogenesis and fatty acid profile in milk. J. Dairy Sci., 90: 1851-1858.

Poungchompu, O., M. Wanapat, C. Wachirapakorn, S. Wanapat and A. Cherdthong, 2009. Manipulation of ruminal fermentation and methane production by dietary saponins and tannins from mangosteen peel and soapberry fruit. Arch. Anim. Nutr., 63: 389-400.

Puchala, R., B.R. Min, A.L. Goetsch and T. Sahlu, 2005. The effect of a condensed tannin-containing forage on methane emission by goats. J. Anim. Sci., 83: $182-186$.

SAS Institute, 1996. User's Guide: Statistic, Version 5. 5th Edn., SAS Institute Inc., USA.

Sliwinski, B.J., M. Kreuzer, H.R. Wettstein and A. Machmuller, 2002. Rumen fermentation and nitrogen balance of lambs fed diets containing plant extracts rich in tannins and saponins and associated emissions of nitrogen and methane. Arch. Tierernahr., 56: 379-392.

Soliva, C.R., I.K. Hindrichsen, L. Meile, M. Kreuzer and A. Machmuller, 2003. Effects of mixtures of lauric and myristic acid on rumen methanogens and methanogenesis in vitro. Lett. Applied Microbiol., 37: 35-39.

Tavendale, M.H., L.P. Meagher, D. Pacheco, N. Walker, G.T. Attwood and S. Sivakumaran, 2005. Methane production from in vitro rumen incubations with Lotus pedunculatus and Medicago sativa and effects of extractable condensed tannin fractions on methanogenesis. Anim. Feed Sci. Technol., 123-124: 403-419.

Wanapat, M., C. Mapato, R. Pilajun and W. Toburan, 2011. Effects of vegetable oil supplementation on feed intake, rumen fermentation, growth performance and carcass characteristic of growing swamp buffaloes. Livest. Sci., 135: 32-37.

Wright, A.D.G. and C.H. Auckland and D.H. Lynn, 2007. Molecular diversity of methanogens in feedlot cattle from Ontario and Prince Edward Island Canada. Applied Environ. Microbiol., 13: 4206-4210.

Wright, A.D.G., X. Ma and N.E. Obispo, 2008. Methanobrevibacter phylotypes are the ominantmethanogens in sheep from Venezuela. Microb. Ecol., 56: 390-394.

Yabuuchi, Y., Y. Matsushita, H. Otsuka, K. Fukamachi and Y. Kobayashi, 2006. Effects of supplemental lauric acid-rich oils in high-grain diet on in vitro rumen fermentation. Anim. Sci. J., 77: 300-307.

$\mathrm{Yu}, \mathrm{Z}$. and M. Morrison, 2004. Improved extraction of PCR-quality community DNA from digesta and fecal samples. Biotechniques, 36: 808-812. 